\title{
Las culturas profundas en la novela latinoamericana. Cinco ensayos del filósofo Eduardo Subirats Rüggeberg acerca de las tradiciones vivas de las antiguas culturas andinas, amazónicas, africanas o mesoamericanas en las novelas de Rulfo, Arguedas, Guimaraes Rosa, Andrade y Roa Bastos. Mito y Mimesis.
}

\section{Darío Henao Restrepo}

El rigor con la ideas, su afán por mostrar el lado oculto de la tradición hispánica y el cuestionamiento de la crisis de nuestra civilización, caracterizada en su visión como una era de desmoronamiento moral, destrucción de la biodiversidad y de ampliación mundial del hambre, marcan en buena parte la vasta trayectoria filosófica de Eduardo Subirats Rüggeberg. Su obra tiene la extraordinaria virtud de provocar la polémica y la reflexión sobre la cultura, la historia y todas las expresiones artísticas de la modernidad. Una lúcida mirada crítica preside la revisión que hace en sus libros sobre todo lo que viene acaeciendo en el mundo después de la modernidad.

Subirats nació en Barcelona en 1947 y se formó primero en siquiatría en su ciudad y luego en filosofía en Paris y Berlín. Ha sido profesor de filosofía, arquitectura, literatura y teoría de la cultura en Sao Paulo, Caracas, Barcelona, Madrid, México, Princeton, y en la actualidad en la Universidad de Nueva York. Un empeño lo caracteriza como intelectual, la configuración de una tradición alternativa a la dominante en el afán por elaborar una crítica radical de la sociedad contemporánea y sus proyecciones culturales. $\mathrm{Su}$ obra impugna siempre la ortodoxia y todos los entramados de intereses con sus profundas raíces históricas e ideológicas. Esto hace parte ineludible de su proyecto intelectual, que tiene en la tradición intelectual española antecedentes en pensadores como Américo Castro, María Zambrano, José María Blanco White o Juan Goytisolo. Ligado también a la tradición crítica centroeuropea de Theodor W. Adorno, Max Horkheimer y Walter Benjamin - con la que su diálogo es permanente -, se destaca asimismo por los fuertes lazos que ha establecido con ciertas ramas del pensamiento y la creación latinoamericanos, una aproximación cada vez más intensa y productiva por su convicción acerca de su gran riqueza y aportes a la civilización. De ahí el interés que le presta a la conquista de América y a todo el proyecto imperial hispano-católico, con la expulsión de las minorías judías y musulmanas, análisis que se propone en su obra 
mayor, El continente vacío (1992), en la que devela el fenómeno colonial americano y toda la destrucción y aplastamiento de las civilizaciones indígenas soportada en el estigma misionero del pecado y el diablo.

Sus más recientes ensayos sobre grandes obras de la literatura latinoamericana del siglo XX - Pedro Páramo de Juan Rulfo, Los Ríos profundos de José María Arguedas, Gran sertón veredas de Joao Guimaraes Rosa, Macunaima de Mario de Andrade y Yo El Supremo de Augusto Roa Bastos - retoman mucho del camino desbrozado en sus análisis sobre la conquista del nuevo mundo e hilvanan una lúcida interpretación de la recreación de los mitos y culturas indígenas por los novelistas escogidos. Subirats reconoce el carácter único, irrepetible y sagrado, de las culturas y los pueblos y controvierte lo que se ha tratado de disminuir como indigenismo en la obra de José María Arguedas, Joao Guimaraes Rosa, Mario de Andrade, Juan Rulfo y Augusto Roa Bastos. Valora en estas obras su restauración poética de una ética, una metafísica y una política humanistas arraigadas en las tradiciones vivas de las antiguas culturas andinas, amazónicas, africanas o mesoamericanas, dotadas de la misma universalidad que pueda atribuirse a la metafísica de León Hebreo, la teoría de los colores de Goethe o la concepción de la naturaleza de Courbet. Para Subirats la integración de estas voces y lenguas antiguas, en muchas ocasiones relacionadas con la experiencia de lo sagrado, ha abierto la literatura latinoamericana del siglo XX a una nueva dimensión de lo poético.

¿Vale entonces volver a estas novelas en una era de destrucción? El viaje hermenéutico propuesto en estos ensayos por Subirats con títulos tan sugestivos como Macunaima: el juego y la risa, El cosmos sagrado de Los Ríos profundos, Pedro Páramo: Zeitroman, La guerra mítica de Grande sertón y Escritura, poder y esquizofrenia: Yo El Supremo, lo confirman con esperanza a lo largo de las 480 páginas que suman estos ensayos. En medio de tanta crisis es refrescante volver a la riqueza de unas culturas que sabiamente los novelistas en cuestión supieron traducir. Este es un acervo con el que los latinoamericanos cuentan para dialogar con el mundo y construir sus propios derroteros. La interpretación de Subirats está sólidamente sustentada mediante una sugerente y original combinación del análisis literario, la investigación histórica, las teorías de la cultura y los diversos saberes de las ciencias humanas y sociales. Método ya probado en libros de Subirats de enorme repercusión internacional como El alma y la muerte, La flor

Poligramas 36, segundo semestre 2011, ISSN 0120-4130. 
y el cristal, Memoria y exilio, La existencia sitiada, Da vanguardia ao posmoderno, Las estrategias del espectáculo, Filosofía y tiempo final y, en toda su complejidad, en El continente vacío, o La ilustración insuficiente en el que puso de presente las limitaciones filosóficas de la Ilustración y la Modernidad hispánicas. Cuando aparece El continente vacío se produce un gran revuelo en España hasta el bloqueo comercial del libro. Vino luego la edición mexicana. Y sin duda, esta obra quedará en los anales como un intento singularmente provocador y una llamada al examen de conciencia de una Europa pletórica de autosatisfacción, sumida hoy en un mundo que no por evangelizado cumple mejor las expectativas más elementales de las doctrinas que lo han inspirado.

Lo que se siente y provoca la lectura de los cinco ensayos filosófico-literarios sobre novelas tan paradigmáticas de las antiguas culturas del continente es la vigencia de la utopía por un mundo armónico, que como insiste Subirats puede y debe estar integrado a lo ancho de un diálogo horizontal entre culturas históricas y lenguas diferentes.

Eduardo Subirats. Actualmente es profesor en New York University. Ha enseñado en las universidades de Sao Paulo, Madrid, Caracas, México y Princeton. Es autor de $D a$ vanguarda ao pós-moderno (Sâo Paulo, 1984); Los malos días pasarán (Caracas, 1992); Linterna Mágica (Madrid, 1997), A cultura como espetaculo (São Paulo, 1989; México, 2001), A penúltima visão do Paraíso (São Paulo, 2001; México 2004), y Memoria y exilio (Madrid 2003); La existencia sitiada (México, 2006) y Filosofía y tiempo final (Madrid 2010). El doctorado en Humanidades de la Universidad del Valle y publicará próximamente la tercera edición aumentada de su obra más importante: El continente vacío (México, 1994). 